\title{
Sugars levels of four sugarcane genotypes in different stem portions during the maturation phase
}

\author{
LAÍS F.M. PEREIRA ${ }^{1}$, VILMA M. FERREIRA ${ }^{2}$, NELSON G. DE OLIVEIRA ${ }^{3}$, PEDRO \\ L.V.S. SARMENTO ${ }^{2}$, LAURÍCIO ENDRES ${ }^{2}$ and IÊDO TEODORO ${ }^{2}$ \\ ${ }^{1}$ Universidade de São Paulo, Faculdade de Agricultura, Caixa Postal 237, 18603-970 Botucatu, SP, Brazil \\ ${ }^{2}$ Universidade Federal de Alagoas, Departamento de Agricultura, Rodovia BR 104, Km 85, s/n, 57100-000 Rio Largo, AL, Brazil \\ ${ }^{3}$ Embrapa Agroenergia, PqEB, s/n, 70770-901 Brasília, DF, Brazil
}

Manuscript received on September 2, 2016; accepted for publication on November 18, 2016

\begin{abstract}
Maturation is a characteristic of sugarcane plant (Saccharum spp.) and even when grown under the same soil and climate conditions the varieties differ on the maturation curve. Thus, studies that allow establishing maturation curves of different sugarcane genotypes in the local soil and climate may indicate the proper harvesting period to ensure better quality of the raw material. This study aimed to analyze the levels of soluble sugars during the maturation phase and assess the technological and productivity indexes of four irrigated sugarcane genotypes in the region of Rio Largo, Alagoas. The experiment was conducted in randomized blocks in a 4 × 2 x 5 factorial: four genotypes (RB92579, RB98710, RB99395 and RB961003), two stem portions (internodes 1-4 and internodes 5-8) and five seasons (82, 49, 25, 13 and 3 days before harvesting), each treatment with three replications. Internodes 1-4 showed the highest levels of reducing sugars, while the largest accumulation of sucrose and total soluble solids occurred in internodes 5-8. RB99395 genotype showed more stability in the sugar levels during sugarcane maturation, which can indicate early maturation and high agricultural yield.
\end{abstract}

Key words: fructose, glucose, sucrose, total soluble solid, yield.

\section{INTRODUCTION}

Sugarcane (Saccharum spp.) is a very important crop in the world's economy, especially as raw material for production of sugar, alcohol, yeast and other derivatives (Cesnik and Miocque 2004). The economic yield of this culture is given by the sucrose production, reducing sugars that are used in the formation of molasses and also fiber, which

Correspondence to: Laís Fernanda Melo Pereira

E-mail: lais.agro@hotmail.com can be used as source of energy in the plant itself (Toppa et al. 2010).

A succession of internodes at different physiological stages comprises the sugarcane stem, i.e., immature (top), at maturation (middle) and mature internodes (bottom). Immature internodes are fibrous, have high concentration of reducing sugars and low sucrose concentration. As these internodes develop, their growth rate progressively decreases until it is null when the stem reaches maturation (Machado 1987). During this process, 
the basal third of the stem has higher sugar content in relation to the middle third, which in turn has higher sugar content compared to the apical third. With advancing maturation, the sucrose content tends to become homogeneous in the various stem portions (Fernandes 1982).

In commercial production, maturation is a continuous process that maybe improved by environmental factors or management practices that paralyze plant growth. These include low temperatures, irrigation suspension, limitation of nitrogen fertilization and application of chemical ripeners (Lingle and Smith 1991, Rodrigues 2013). One way often used to monitor sugarcane maturation is through technological indexes that are evaluated in industry and determine the quality of the raw material.

Given the above, this study aimed to analyze the levels of soluble sugars during the maturation phase and assess technological and productivity indexes of four irrigated sugarcane genotypes in the region of Rio Largo, state of Alagoas, in the 2012/2013 cropping season.

\section{MATERIALS AND METHODS}

\section{DESCRIPTION OF THE EXPERIMENTAL AREA}

The research was conducted in the experimental area located at Rio Largo $\left(09^{\circ} 28^{\prime} \mathrm{S}, 35^{\circ} 49^{\prime} \mathrm{W}\right.$ and $127 \mathrm{~m}$ above sea level), state of Alagoas, Brazil. The soil of the area was classified as Cohesive Argisolic Yellow Latosol of medium-clayey texture with declivity less than $3 \%$. The climate is hot and semi-humid type with average annual rainfall of $1,818 \mathrm{~mm}$ (Souza et al. 2004).

Prior to the experiment installation, chemical analysis of soil in layers 0-20 and 20-40 cm deep in the profile was carried out. Based on these results, $500 \mathrm{~kg} \mathrm{ha}^{-1}$ of dolomitic lime were applied to increase the soil saturation to $60 \%$ (Oliveira et al. 2007), following harrowing, plowing and foundation fertilization using $150 \mathrm{~kg} \mathrm{ha}^{-1} \mathrm{~N}, 195 \mathrm{~kg}$ $\mathrm{ha}^{-1} \mathrm{P}_{2} \mathrm{O}_{5}$ and $230 \mathrm{~kg} \mathrm{ha}^{-1} \mathrm{~K}_{2} \mathrm{O}$.

\section{CULTURE INSTALLATION}

The experimental design was a randomized block in a 4 (genotypes) x 2 (stem portion) x 5 (seasons) factorial scheme with three replications. Sugarcane genotypes were represented by RB92579, RB98710, RB99395 varieties and RB961003 clone, being selected by high agricultural productivity, sugar content and maturation time. Two stem portions were assessed: internodes 1-4 and internodes $5-8$, considering that internode 1 is that located immediately below leaf +1 , which is the first leaf from apex to bottom presenting visible atrium. Evaluations were performed at five seasons 82, 49, 25, 13 and 3 days before harvest (DBH).

The experimental plot consisted of two double lines of $10 \mathrm{~m}$ in length. Planting furrows were opened with spacing of $1.4 \mathrm{~m}$ between double rows and $0.4 \mathrm{~m}$ within the double row. Planting was held on 22 dez. 2011, with density of about 15 buds per linear meter of furrow and depth of $0.25 \mathrm{~m}$. Stems of about 12 months of age were placed in the furrow bottom in order to be "foot with tip" being chopped with a machete, leaving at least three gems per billet. Then, the stems were covered with a soil layer of $\pm 0.07 \mathrm{~m}$.

\section{CROP MANAGEMENT}

In the first 15 days after planting, the crop was irrigated by low-pressure conventional sprinkler, applying a $70 \mathrm{~mm}$ water slide and split with two-day irrigation interval to ensure uniform germination. Subsequently, the culture was irrigated by dripping with drip tapes of $22 \mathrm{~mm}$ and self-compensating emitters every $0.5 \mathrm{~m}$ with average flow rate of $1 \mathrm{~L}$ $\mathrm{ha}^{-1}$ and pressure of $1.4 \mathrm{~kg} \mathrm{~cm}^{-2}$. In the rainy season (17 may to 10 sep. 2012), irrigation was suspended and resumed in the dry season (from 20 sep. 2012). 
The amount of water applied was determined as a function of the crop evapotranspiration (ETc), which was calculated by multiplying the reference evapotranspiration (ETo) by the crop coefficient $(\mathrm{Kc})$ in the initial, intermediate and final phase of sugarcane, according to method proposed by Allen et al. (1998). Weather conditions such as rainfall, air temperature and relative humidity were daily recorded in automatic data acquisition weather station micrologger located $400 \mathrm{~m}$ from the experiment. Based on temperature and relative humidity data, the air vapor pressure deficit (VPD) was also calculated according to FAO (1991).

Throughout the culture development, control of native plants was performed through chemical treatment and hand hoeing whenever necessary. At 60 days after planting, topdressing was held with $20 \mathrm{~kg} \mathrm{ha}^{-1} \mathrm{~N}$, using ammonium sulfate as nitrogen source. In the final stage of the crop cycle, at $25 \mathrm{DBH}$, irrigation was suspended to optimize maturation and increase the sucrose content of stems.

\section{DETERMINATION OF SUGARS AND TOTAL SOLUBLE SOLIDS}

After 82, 49, 25, 13 and 3 DBH (from 14 nov. 2012 to 01 feb. 2013), three stems of each sugarcane genotype per experimental plot were randomly collected and immediately taken to the laboratory. Stems were cut into two portions, internodes $1-4 \mathrm{~cm}$ and $5-8 \mathrm{~cm}$. These portions were chosen because they are the regions of highest growth, with internodes still immature and possibly with greater differences in concentrations of soluble sugars.

Then, stems were passed in electric milling and filtered to obtain the juice. After juice extraction, a few drops were placed on the prism of the portable digital refractometer to obtain the contents of total soluble solids, expressed in ${ }^{\circ}$ Brix. About 2 $\mathrm{ml}$ of juice samples were also collected using an automatic pipette, keeping them in microtubes arranged in a Styrofoam box with ice to reduce chemical changes. Subsequently, juice samples were centrifuged at $14,000 \mathrm{xg}$ for 10 minutes at $4{ }^{\circ} \mathrm{C}$ and supernatants were transferred to $1.5 \mathrm{ml}$ microtubes, being stored in freezer at $-20{ }^{\circ} \mathrm{C}$ for subsequent chemical analysis and precipitates were discarded.

The fructose, glucose and sucrose contents were determined by High-Performance liquid chromatography (HPLC) (Hunt et al. 1977) using Shimadzu U-20 chromatograph equipped with an oven (CTO-20A), automatic sample injector (SIL10Ai), refractive index detector (RID10A), a 25 cm x 4.6 mm column (Shim-pack CLC-NH $\mathrm{N}_{2}(\mathrm{M})$ ), stationary phase (Aminopropyl group), separation mode (Reversed, normal, ion, exchange) and pre column ( $\left.\mathrm{G} \mathrm{NH}_{2}, 8 \mathrm{~mm}\right)$. Fructose, glucose and sucrose solutions were used as calibration standard and acetonitrile and ultrapure water at a ratio of 75:25 v/v were used as eluent.

The oven temperature used was $40{ }^{\circ} \mathrm{C}$. Sugarcane juice samples from the four sugarcane genotypes were thawed in a water bath with ice and filtered with Millipore disposable filter (Hidrophilic PVDF) with membranes $0.45 \mu \mathrm{m}$ of pore and 33 $\mathrm{mm}$ in diameter, with the aid of $5 \mathrm{ml}$ syringes. Then, samples were diluted in ultrapure water at a ratio of 1:5. Shortly after, $1 \mathrm{ml}$ fractions were transferred to $1.5 \mathrm{ml}$ glass vials with screw cap and PTFE/Silicone septum, starting the readings on the HPLC. The injection volume was $20 \mu 1$.

\section{HARVEST, EVALUATION OF TECHNOLOGICAL AND YIELD INDEXES}

Sugarcane was manually harvested without burning on $04 \mathrm{feb}$. 2013. Stems produced in a double line of $5 \mathrm{~m}$ in length of the sample area were collected, which were weighed and sent to the laboratory located at Rio Largo, AL, for the characterization of technological indexes by analyzing the juice extracted by the hydraulic press method described by Fernandes (2000). The following parameters were determined: content of total soluble solids 
( ${ }^{\circ}$ Brix); sugarcane Pol (\%); Juice Purity (\%); Industrial Fiber (\%); Reducing Sugars (\%); Total reducing sugars (\%), Total Recoverable Sugars $\left(\mathrm{kg} \mathrm{t}^{-1}\right)$ and Agricultural yield ( $\left.\mathrm{t} \mathrm{ha}^{-1}\right)$, according to Consecana (2006).

\section{STATISTICAL ANALYSIS}

Results were submitted to analysis of variance by the $\mathrm{F}$ test with subsequent comparison of means using the Tukey test $(p<0.05)$ with the statistics program SISVAR (Variance Analysis System, version 5.3). Data of sugars and total soluble solids were analyzed in a split plot arrangement in time.

\section{RESULTS}

\section{METEOROLOGICAL CONDITIONS}

The amount of water supplied to plants considering the sum of rainfall and irrigation for $90 \mathrm{DBH}$ was $371 \mathrm{~mm}$. The highest crop water demand occurred between 90 and $70 \mathrm{DBH}$, which was around $5.9 \mathrm{~mm} \mathrm{day}^{-1}$, and from that period, the crop evapotranspiration (ETc) remained constant, averaging $3.4 \mathrm{~mm}$ day $^{-1}$ (Figure 1a).

During the experimental period, the air temperature ranged from 25.9 to $27.5^{\circ} \mathrm{C}$, averaging $26.4{ }^{\circ} \mathrm{C}$ (Figure $1 \mathrm{~b}$ ). The relative humidity averaged $73 \%$; however, at $60 \mathrm{DBH}$, moisture was more pronounced (82\%) (Figure 1b). In the period from 30 to $10 \mathrm{DBH}$, there was a decrease of moisture due to the increase in temperature in the region, which directly contributed to the increase in the vapor pressure deficit in the same period, ranging from 1.0 to $1.2 \mathrm{kPa}$ (Figure 1c).

\section{CONTENT OF SUGARS AND TOTAL SOLUBLE SOLIDS}

Internodes 1-4 showed fructose and glucose levels significantly higher than internodes 5-8 in most assessment periods (Figure 2). RB92579 genotype at $49 \mathrm{DBH}$ (Figures 2a, 2e) and RB961003 genotype at $13 \mathrm{DBH}$ (Figures 2d, 2h) showed an increase in fructose and glucose levels in internodes 5-8. RB99395 was the only genotype that maintained fructose and glucose contents practically constant in both stem portions throughout the maturation period, with an increase of $0.5 \%$ fructose at 25 DBH (Figure 2c) and an increase of $0.6 \%$ glucose at 3 DBH (Figure 2g), both in internodes 1-4. Except for RB92579 genotype, there were reductions in fructose and glucose levels in internodes 5-8 at 3 DBH (Figure 2).

The sucrose content of sugarcane juice was higher in internodes 5-8 in all genotypes and periods analyzed (Figure 3). The sucrose levels in RB99395 genotype remained constant throughout the assessment period, with average value of $15.1 \%$ sucrose in sugarcane juice in internodes 5-8, standing out among the other genotypes (Figure 3c). On the other hand, RB961003 clone was the genotype that showed the lowest sucrose values, averaging only $6.4 \%$ sucrose in the same stem portion (Figure 3d).

In summary, internodes 5-8 showed high levels of soluble solids in all genotypes (Figure 3). At 3 DBH, RB99395 and RB961003 genotypes showed increments of 3 and $2{ }^{\circ}$ Brix (Figures $3 \mathrm{~g}, 3 \mathrm{~h}$ ), respectively, in the same stem portion in relation to the previous period.

In general, during the maturation process, internodes 1-4 showed the highest fructose and glucose concentrations, and RB92579 was the genotype with the lowest levels of reducing sugars in this stem portion, $1.2 \%$ fructose and $1.5 \%$ glucose. RB961003 showed high glucose levels in internodes 5-8, and when compared with the other genotypes, it showed an average of $1.8 \%$ glucose in the sugarcane juice (Table I).

Sucrose and ${ }^{\circ}$ Brix levels were higher in internodes 5-8 in all genotypes analyzed, with differences among genotypes. RB99395 showed the highest sucrose concentrations in the juice in both stem portions analyzed, especially in internodes $5-8$, which showed, on average, $15.1 \%$ sucrose. 

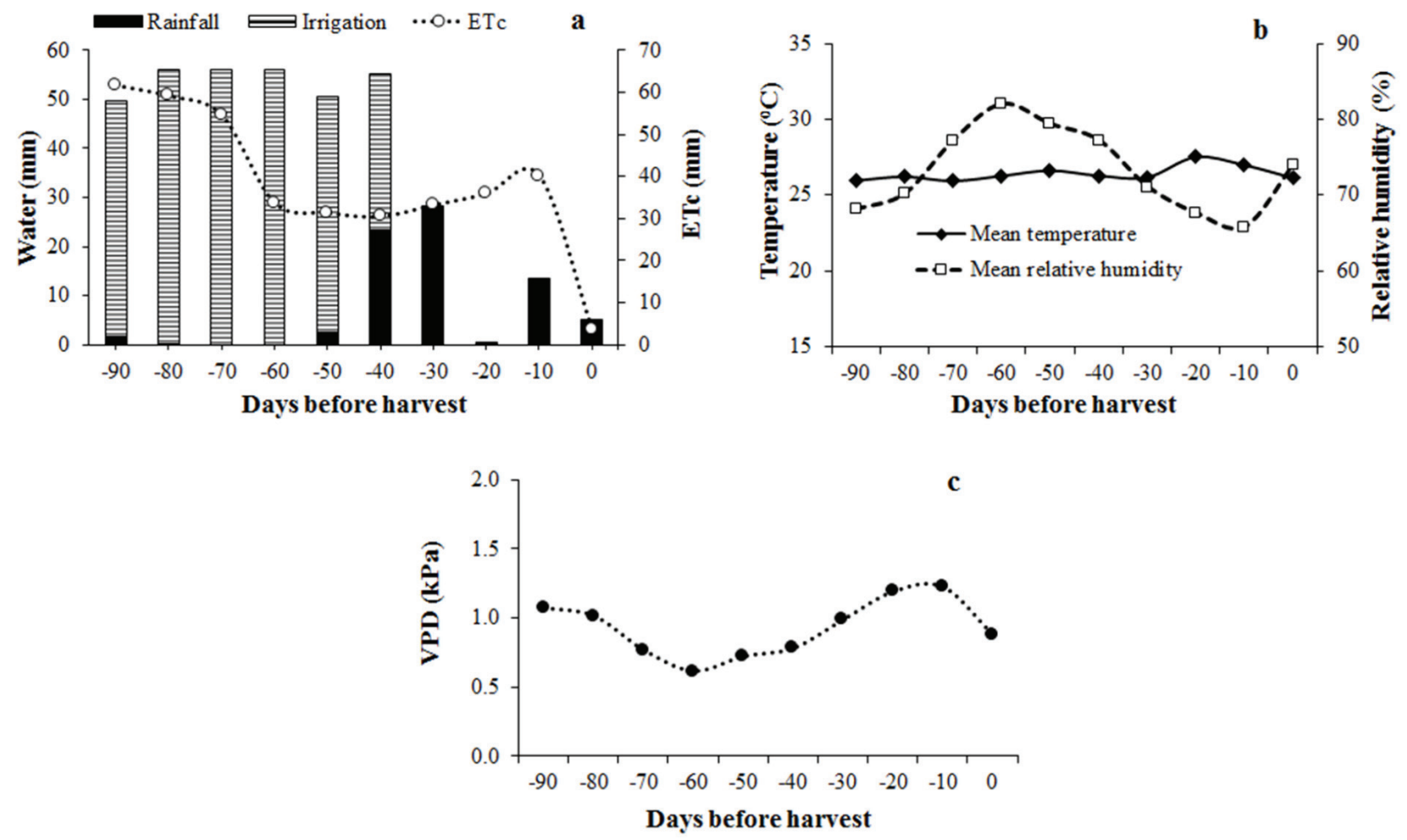

Figure 1 - Rainfall, irrigation and evapotranspiration (ETc) of sugarcane (a), temperature and relative humidity (b) and vapor pressure deficit (VPD) of air (c) in the region of Rio Largo, AL, from 06 nov. 2012 to 04 feb. 2013.

TABLE I

Mean levels of fructose, glucose, sucrose and soluble solids ( Brix) in the juice of four sugarcane genotypes in internodes 1-4 and 5-8 at 90 days before harvest in the region Rio Largo, AL.

\begin{tabular}{|c|c|c|c|c|}
\hline \multirow{3}{*}{ Genotypes } & \multicolumn{2}{|c|}{ Fructose (\%) } & \multicolumn{2}{|c|}{ Glucose (\%) } \\
\hline & Internodes & Internodes & Internodes & Internodes \\
\hline & 1 to 4 & 5 to 8 & 1 to 4 & 5 to 8 \\
\hline RB92579 & $1.2 \mathrm{Ac}$ & $0.9 \mathrm{Bb}$ & $1.5 \mathrm{Ac}$ & $1.1 \mathrm{Bc}$ \\
\hline RB98710 & $1.7 \mathrm{Aa}$ & $1.0 \mathrm{Ba}$ & $2.1 \mathrm{Aa}$ & $1.4 \mathrm{Bb}$ \\
\hline RB99395 & $1.4 \mathrm{Ab}$ & $0.5 \mathrm{Bc}$ & $2.0 \mathrm{Aa}$ & $0.7 \mathrm{Bd}$ \\
\hline RB961003 & $1.4 \mathrm{Ab}$ & $1.1 \mathrm{Ba}$ & $1.8 \mathrm{Ab}$ & $1.8 \mathrm{Ba}$ \\
\hline VC1 (\%) & \multicolumn{2}{|c|}{7.3} & \multicolumn{2}{|c|}{5.5} \\
\hline VC2 $(\%)$ & \multicolumn{2}{|c|}{7.9} & \multicolumn{2}{|c|}{8.1} \\
\hline \multirow{3}{*}{ Genotypes } & \multicolumn{2}{|c|}{ Sucrose (\%) } & \multicolumn{2}{|c|}{${ }^{\circ}$ Brix } \\
\hline & Internodes & Internodes & Internodes & Internodes \\
\hline & 1 to 4 & 5 to 8 & 1 to 4 & 5 to 8 \\
\hline RB92579 & $2.2 \mathrm{Bb}$ & $8.9 \mathrm{Ac}$ & $7.2 \mathrm{Bb}$ & $13.5 \mathrm{Ab}$ \\
\hline RB98710 & $1.4 \mathrm{Bc}$ & $10.2 \mathrm{Ab}$ & $7.2 \mathrm{Bb}$ & $13.7 \mathrm{Ab}$ \\
\hline RB99395 & $4.5 \mathrm{Ba}$ & $15.1 \mathrm{Aa}$ & $9.7 \mathrm{Ba}$ & $16.5 \mathrm{Aa}$ \\
\hline RB961003 & $1.0 \mathrm{Bc}$ & $6.4 \mathrm{Ad}$ & $6.4 \mathrm{Bb}$ & $11.3 \mathrm{Ac}$ \\
\hline VC1 (\%) & \multicolumn{2}{|c|}{7.8} & \multicolumn{2}{|c|}{5.4} \\
\hline VC2 (\%) & \multicolumn{2}{|c|}{10.2} & \multicolumn{2}{|c|}{8.4} \\
\hline
\end{tabular}

Means followed by the same capital letter in line and small letter in column do not differ at Tukey test $(p<0.05)$. VC1 $=$ variation coefficient of the plot. VC2 = variation coefficient of the subplot. 

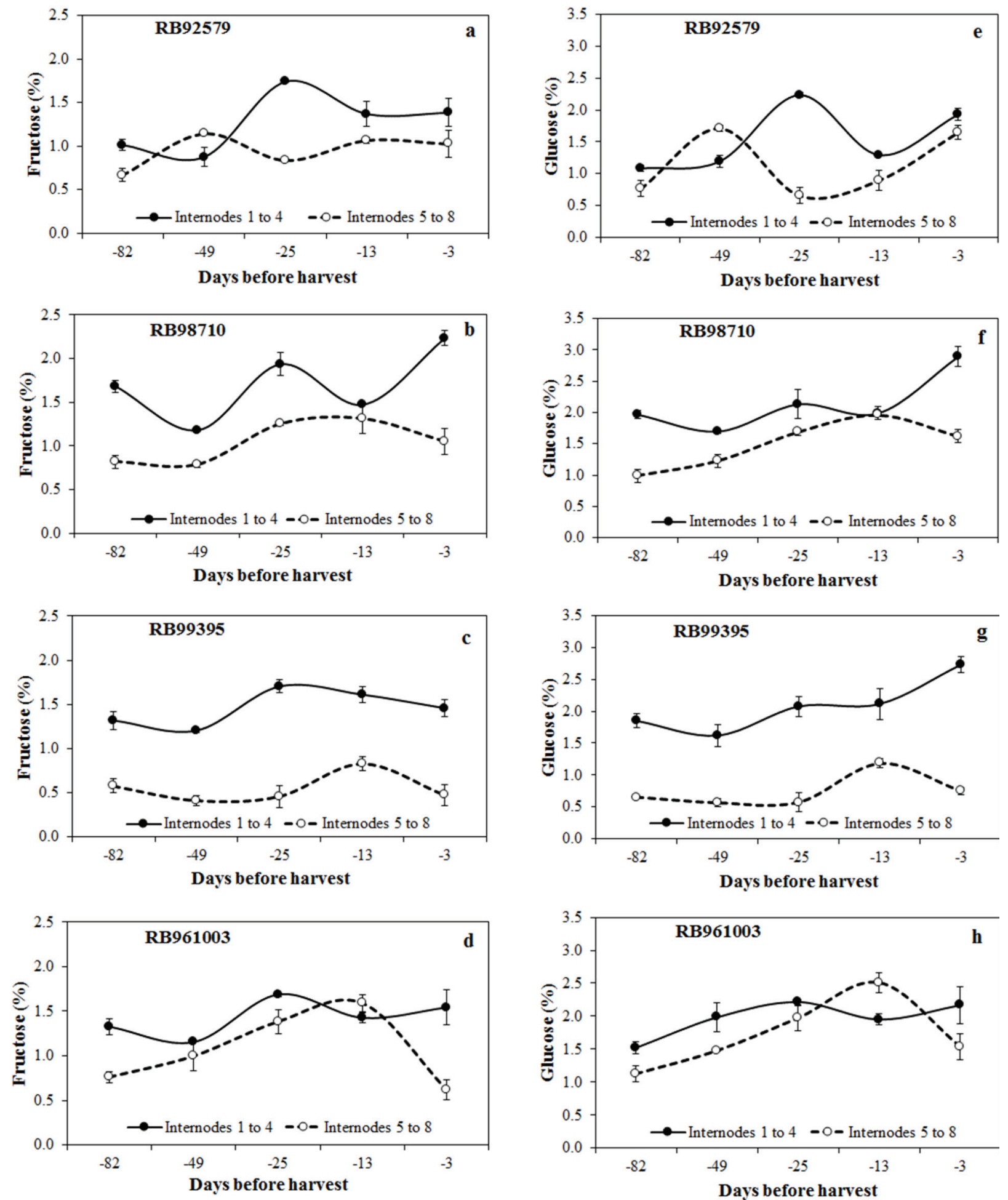

Figure 2 - Fructose (a, b, $\mathbf{c}$ and $\mathbf{d})$ and glucose levels (e, $\mathbf{f}, \mathbf{g}$ and $\mathbf{h}$ ) in the juice of four sugarcane genotypes in internodes 1-4 and 5-8 as a function of days before harvest in the region of Rio Largo, AL. Bars indicate the mean standard deviation of three observations. 

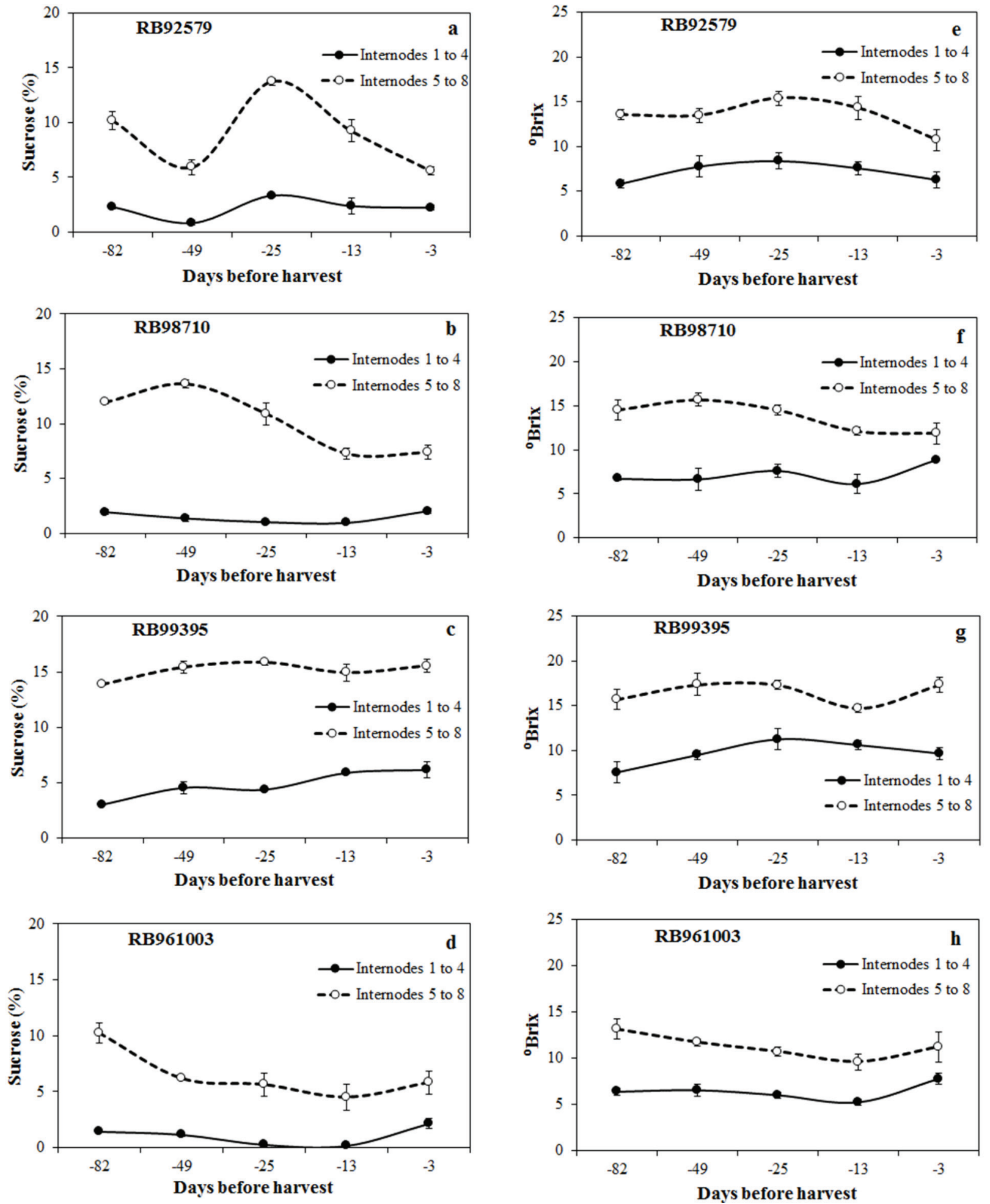

Figure 3 - Levels of sucrose (a, b, $\mathbf{c}$ and $\mathbf{d}$ ) and total soluble solids ( ${ }^{\circ}$ Brix) (e, f, $\mathbf{g}$ and $\mathbf{h}$ ) in the juice of four sugarcane genotypes in internodes 1-4 and 5-8 as a function of days before harvest in the region of Rio Largo, AL. Bars indicate the mean standard deviation of three observations. 
RB961003 genotype showed the lowest levels of this sugar in internodes 5-8, with average value of $6.4 \%$, since it showed high levels of reducing sugars in the same stem portion. RB99395 was the genotype that accumulated ${ }^{\circ}$ Brix in both stem portions during the maturation period (Table I).

\section{TECHNOLOGICAL INDEXES AND SUGARCANE} YIELD

In the analysis of juice extracted from the entire sugarcane, including top, middle and bottom internodes at harvest, the ${ }^{\circ}$ Brix levels did not differ among genotypes, with average values from 20.4 to $21.3^{\circ}$, and these levels were higher than those obtained at 82, 49, 25, 13 and 3 DBH (Table II).

Genotypes showed sugarcane Pol values between 14.6 and $15.1 \%$ and the fiber contents remained between 12.8 and $13.5 \%$. Despite the fluctuation in the glucose and fructose levels in the different stem portions at $90 \mathrm{DBH}$, there were no differences among genotypes studied for reducing sugars (RS) in the final stem evaluation, ranging from 0.6 to $0.7 \%$ (Table II).

In this work, the different genotypes showed average value of $16.4 \%$ for total reducing sugars (TRS). There was no difference among genotypes for total recoverable sugars (TR), with average yield of $146.0 \mathrm{~kg}$ sugar $\mathrm{t}^{-1}$. Evaluating agricultural productivity (TCH), RB99395 stood out among the others with average yield of 152.9 tons of stems per hectare; however, it did not differ from RB92579 and RB98710. RB961003 clone showed the lowest average agricultural productivity (Table II).

\section{DISCUSSION}

The study area is located in the tableland of the state of Alagoas, characterized by a semi-humid tropical climate with rainy season between March and August and dry season from September to February. Rainfall in the region is influenced by maritime tropical air mass and penetration of cold polar air, with average annual rainfall between 1,500 and 2,000 mm, with minimum total of $41 \mathrm{~mm}$ in December and maximum of $294 \mathrm{~mm}$ in July. The average monthly relative humidity shows values above $70 \%$ and the air temperature ranged from 26.0 to $32.8^{\circ} \mathrm{C}$ for maximum temperature and from $18.3{ }^{\circ} \mathrm{C}$ to $23.2{ }^{\circ} \mathrm{C}$ for the minimum temperature (Souza et al. 2004, 2005).

Abreu et al. (2013) evaluated interactions between meteorological variables and the yield components of six sugarcane varieties in thetableland of Alagoas and found that the rainfall irregularity in the region promotes different responses of varieties, both of growth and productivity, in the different cultivation cycles. Inman-Bamber and Smith (2005) reported that the temporal variation of soil moisture conditions caused by the rainfall irregularity is the most relevant factor in the yield oscillation of this culture.

Sugarcane stem has genetically suitable potential to accumulate sugars, mainly sucrose. Under ideal growing conditions, this potential is optimized with maturation, which takes place at the end of the plant cycle (Machado 1987, Santos et al. 2011). Sugarcane maturation depends on a complex combination of climatic variables, genetic potential and crop management (Cardozo and Sentelhas 2013).

Studies have shown that sucrose accumulation in stems in the maturation phase is favored by relatively low temperatures, which reduce the absorption of nutrients and plant growth, and a period of water restriction, because the dehydration of plant tissues forces the conversion of reducing sugars into sucrose. During this process, sucrose content increases to reach extreme limits from 12 to $18 \%$, as the other sugars such as glucose and fructose have their contents reduced by up to limits of $0.2 \%$ (Marafon 2012)

The increase in fructose and glucose levels found in internodes 5-8 in RB92579 and RB961003 genotypes at 49 and $13 \mathrm{DBH}$, respectively (Figure 2) 
TABLE II

Technological ( Brix, Pol, fiber, purity, reducing sugars (RS) and total reducing sugars (TRS)) and productivity indexes (total recoverable sugars (TR) and agricultural yield (TCH)) of four irrigated sugarcane genotypes in the region Rio Largo, AL, 2013.

\begin{tabular}{|c|c|c|c|c|c|c|c|c|}
\hline Genotypes & ${ }^{\circ} \mathrm{Brix}$ & $\begin{array}{l}\text { Pol } \\
(\%)\end{array}$ & $\begin{array}{c}\text { Fiber } \\
(\%)\end{array}$ & $\begin{array}{c}\text { Purity } \\
(\%)\end{array}$ & $\begin{array}{l}\text { RS } \\
(\%)\end{array}$ & $\begin{array}{l}\text { TRS } \\
(\%)\end{array}$ & $\begin{array}{c}\text { TR } \\
\left(\mathrm{kg} \mathrm{t}^{-1}\right)\end{array}$ & $\begin{array}{c}\text { ТСH } \\
\left(\mathrm{t} \mathrm{ha}^{-1}\right)\end{array}$ \\
\hline RB92579 & 20.7 & 14.9 & 12.8 & 83.6 & 0.7 & 16.3 & 145.3 & $125.9 \mathrm{ab}$ \\
\hline RB98710 & 21.3 & 14.6 & 13.5 & 86.1 & 0.7 & 16.2 & 144.4 & $115.9 \mathrm{ab}$ \\
\hline RB99395 & 20.4 & 15.1 & 13.1 & 87.7 & 0.7 & 16.6 & 147.8 & $152.9 \mathrm{a}$ \\
\hline \multirow[t]{2}{*}{ RB961003 } & 20.4 & 15.0 & 12.9 & 88.2 & 0.6 & 16.4 & 146.5 & $108.0 \mathrm{~b}$ \\
\hline & ns & ns & ns & ns & $\mathrm{ns}$ & ns & ns & * \\
\hline VC (\%) & 3.9 & 5.2 & 5.5 & 3.5 & 9.6 & 4.9 & 4.9 & 11.6 \\
\hline
\end{tabular}

${ }^{\mathrm{ns}}$ not significant by the $\mathrm{F}$ test. *Means followed by the same letter in the column do not differ at Tukey test $(p<0.05)$. VC $=$ variation coefficient.

probably occurred by influences of management and climate conditions, as at $49 \mathrm{DBH}$ was preceded by an excessive amount of water in the soil, especially by irrigation, combined with low crop evapotranspiration (Figure 1a), while 13 DBH was marked by an increase in temperature, averaging $27.5^{\circ} \mathrm{C}$ (Figure 1b). The application of $150 \mathrm{~kg} \mathrm{ha}^{-1}$ of $\mathrm{N}$ at planting and $20 \mathrm{~kg} \mathrm{ha}^{-1} \mathrm{~N}$ at topdressing may have favored vegetative growth, delayed maturation and reduced percentage of sucrose by increasing the content of reducing sugar. In contrast, at $3 \mathrm{DBH}$, all genotypes except for RB92579 showed reductions in the levels of fructose and glucose in internodes 5-8 (Figure 2), which would be justified by the suspension of water supply and reduction in the metabolic activity in the growing apical meristem.

Sucrose is the main form by which carbohydrates are translocated from leaves to the rest of the plant by phloem aiming to provide carbon and energy needed for growth and accumulation of reserve products (Felix et al. 2009). Sugarcane maturation is a physiological process involving the synthesis of sugars in leaves, translocation of formed products and storage of sucrose in the stem (Fernandes 1982).
Sucrose contents in internodes 5-8 were higher than those in internodes 1-4 in all genotypes analyzed (Figure 3), as expected, since sucrose is found in increasing concentrations from bottom to top of the stem. Qudsieh et al. (2001) studied the chemical changes of sugarcane juice at different stem portions during development and maturation and found that juice extracted from both middle and bottom stem portions showed the highest levels of sucrose and total soluble solids, whereas fructose and glucose levels were reduced in relation to the top portion of the stem.

Sugarcane quality cannot be analyzed only by its sucrose content, although it is the most important indicator, but rather by a number of other variables responsible for its yield in the industry (Ribeiro et al. 1999). Through studies, sugarcane maturation can be evaluated by technological indexes such as Pol, Brix, Purity and Reducing Sugars (Silva and Segato 2011).

Pol refers to the apparent sucrose content contained in sugarcane juice determined by saccharimetric methods. The higher the content, the more mature sugarcane is. Immature sugarcane has high content of reducing sugars and color 
precursors compounds, which reduce Pol values, resulting in juice with darker color (Ripoli and Ripoli 2004). According to the authors, Pol greater than $14 \%$ is considered adequate in terms of quality to industrialization. This was verified in this study, which showed that sugarcane was ripe at harvest.

Dinardo et al. (2011) evaluated the Pol of several sugarcane cultivars over the 2009/2010 cropping season and found a variation in apparent sucrose content in all cultivars, characterized by an increase with the advancement of phenological stages. According to Rodrigues and Santos (2011), when it comes to mature sugarcane, there is a close relationship between apparent percentage of soluble solids and sucrose content in the solution, and sugarcane is considered mature with minimum Brix of $18^{\circ}$, among other factors.

Overall, the fiber content of genotypes was on average $13.1 \%$ (Table II). Similar results were found by Silva et al. (2014), who studied the productive potential of different sugarcane varieties grown in irrigated conditions. According to Dias et al. (2012), the fluctuation in fiber content among varieties is a genetic trait and the higher the sucrose content of varieties, the lower their fiber content.

The supply of raw materials of technological quality in order to provide economic extraction of sugars is one of the greatest needs of the sugar and alcohol industry (Leite et al. 2010). Improvements in sugar yield may be achieved by increases in juice purity, which represents the proportion of sucrose in total sugars (Lingle and Smith 1991). During the harvest process, it is important to obtain values greater than $80 \%$ purity, because the higher its value, the lower the amount of impurities in the juice and consequently the greater its economic value (Assis et al. 2004). The high quality of the raw material was evidenced in this work. Similar results were also found by Carvalho et al. (2008).

Sucrose accumulation during the maturation process occurs simultaneously with reductions in the content of reducing sugars and increased purity.
Demetrio et al. (2008) analyzed ten RB's clones and found that the content of reducing sugars ranged from 0.4 to $0.6 \%$, indicating that sugarcane was suitable for industrialization, considering that values can be up to $1.5 \%$ at the beginning of harvest, and $1 \%$ in the course of the cropping season.

Total reducing sugars (TRS) are all sugars in the sugarcane in the form of reducing sugars in which all sucrose was converted into glucose and fructose (Fernandes 2000). Thus, the TRS values must follow the trend of Pol values, increasing during the maturation process (Henrique et al. 2011). The genotypes under study showed similar TRS results, although there were differences in the levels of sugars in stem portions during the maturation period.

Total recoverable sugars (TR) indicate the amount of total sugars in the sugarcane mainly consisting of sucrose and reducing sugars, reduced by $11 \%$, which is the average loss allowed in the industrial process (Consecana 2006). Costa et al. (2011) point out that TR is the most important parameter both for industry and for producers, since industrial plants elaborate the price paid to producers based on it.

The results of this study showed differences among genotypes for agricultural productivity. According to Dantas Neto et al. (2006), the yield of irrigated sugarcane depends on the amount of water applied, irrigation management combined with adequate amount of fertilizer, variety, cutting age, type of soil and climate. Therefore, it is suggested that the occurrence of rainfall in the maturation period combined with irrigation and fertilization management may have influenced the sugarcane yield of the different genotypes.

In conclusion, sugarcane juice extracted from internodes 1-4 show higher glucose and fructose levels, while the greatest accumulation of sucrose and soluble solids occurs in internodes 5-8, showing higher maturation in the bottom portion of stems. RB92579, RB98710, RB99395 and 
RB961003 genotypes do not differ in relation to the contents of total soluble solids, Pol, juice purity, industrial fiber, reducing sugars, total reducing sugars and total recoverable sugars when grown under the soil and climatic conditions of Rio Largo, AL. RB99395 shows higher stability in the content of sugars during the maturation process, which may indicate early maturation and high industrial productivity of this variety.

\section{REFERENCES}

ABREU ML, SILVA MA, TEODORO I, HOLANDA LA AND SAMPAIO NETO GD. 2013. Growth and productivity of sugarcane varieties as affected by water availability in the Coastal Tablelands of the Alagoas State, Brazil. Bragantia 72: 262-270.

ALLEN RG, PEREIRA LS, RAES D AND SMITH M. 1998. Crop evapotranspiration: guidelines for computing crop water requirements. Irrig and Drain Paper 56: 2-15.

ASSIS PCO, LACERDA RD, AZEVEDO HM, DANTAS NETO J AND FARIAS CHA. 2004. Response of technological parameters of sugarcane to different laminate of irrigation and manuring. Rev Biol Ciênc Terra 4: 01-12.

CARDOZO NP AND SENTELHAS PC. 2013. Climatic effects on sugarcane ripening under the influence of cultivars and crop age. Sci Agric 70: 449-456.

CARVALHO CM, AZEVEDO HM, DANTAS NETO J, MELO EP, SILVA CTS AND GOMES FILHO RR. 2008. Response of technical parameters of third ratoon of sugarcane subjected to different levels of irrigation. Rev Bras Ciênc Agrár 3: 337-342.

CESNIK R AND MIOCQUE J. 2004. Melhoramento da canade-açúcar. Embrapa Informação Tecnológica, Jaguariúna, SP, Brazil, 307 p.

CONSECANA. 2006. Sistema de remuneração da tonelada de cana-de-açúcar com base o açúcar total recuperável (ATR) safra 2006/2007. Recife, PE, Brazil.

COSTA CTS, FERREIRA VM, ENDRES L, FERREIRA DTRG AND GONÇALVES ER. 2011. Growth and yield of four varieties of sugarcane (Saccharum sp.), in the third ratoon. Rev Caatinga 24: 56-63.

DANTAS NETO J, FIGUEREDO JLC, FARIAS CHA, AZEVEDO HM AND AZEVEDO CAV. 2006. Response of sugarcane, second leaf, to irrigation levels and topdressing manuring. Rev Bras Eng Agríc Ambient 10: 283-288.

DEMETRIO PA, ZONETTI PC AND MUNHOZ REF. 2008. Promising RBs sugarcane clones evaluation regarding sugarcane borer (Diatraea saccharalis) in northwest of Paraná state. Iniciação Científica Cesumar 10: 13-16.
DIAS CMO, CORSATO CE, SANTOS VM AND SANTOS AFS. 2012. Phytotechnical, production and agroindustrial indicators in sugarcane cultivated under two water regimes. Rev Caatinga 25: 58-65.

DINARDO V, SILVA NETO HF, TASSO JÚNIOR LC, CAMILOTTI F AND MARQUES MO. 2011. Avaliação da pol em cana-de-açúcar com ciclo de maturação em início da safra. Editora FATEC-JB, Jaboticabal, SP, Brasil.

FAO - FOOD AND AGRICUTURE ORGANIZATION. 1991. Report on the expert consultation on procedures for revision of FAO guidelines for prediction of crop water requirements. Rome, Italy.

FELIX JM, PAPINI-TERZI FS, ROCHA FR, VÊNCIO RZN, VICENTINI R, NISHIYAMA JR MY, ULIAN EC, SOUZA GM AND MENOSSI M. 2009. Expression profile of signal transduction components in a sugarcane population segregating for sugar content. Trop Plant Biol 2: 98-109.

FERNANDES AC. 1982. Refratômetro de campo. Boletim Técnico Copersucar 19: 5-12.

FERNANDES AC. 2000. Cálculos na agroindústria da canade-açúcar. STAB, Piracicaba, SP, Brasil, 193 p.

HENRIQUE CM, CAMARGO MS, FOLTRAN DE AND WYLER P. 2011. Technologycal quality and harvest time of sugarcane varieties growing at Tietê, SP. Colloquium Agrariae 7: 01-08.

HUNT RS, JACKSON PA, MORTLOK RE AND KIRTE RS. 1977. Quantitative determination of sugar in foodstuffs by high performance liquid chromatography. Analyst 102: 917-920.

INMAN-BAMBER NG AND SMITH DM. 2005. Water relations in sugarcane and response to water defcits. Field Crop Res 92: 185-202.

LEITE GHP, CRUSCIOL CAC, SIQUEIRA GF AND SILVA MA. 2010. Technological quality at different portions of the stalk and productivity of sugarcane under effect of ripeners. Bragantia 69: 861-870.

LINGLE SE AND SMITH RC. 1991. Sucrose metabolism related to growth and ripening in sugarcane internodes. Crop Sci 31: 172-177.

MACHADO EC. 1987. Sugarcane production physiology. In: Paranhos SB. Sugarcane: cultivation and use. Editora Fundação Cargill, Campinas, SP, Brazil, p. 56-87.

MARAFON AC. 2012. Análise quantitativa de crescimento em cana-de-açúcar: uma introdução ao procedimento prático. Embrapa Tabuleiros Costeiros, Aracaju, SE, Brasil, 29 p.

OLIVEIRA MW, FREIRE FM, MACÊDO GAR AND FERREIRA JJ. 2007. Nutrição mineral e adubação da cana-de-açúcar. Informe Agropecuário 28: 30-43.

QUDSIEH HYM, YUSOF S, OSMAN AAND RAHMAN RA. 2001. Physico-chemical changes in sugarcane (Saccharum officinarum var Yellow Cane) and the extracted juice at 
different portions of the stem during development and maturation. Food Chem 75: 131-137.

RIBEIRO CAF, BLUMER SAG AND HORII J. 1999. Fundamentos de tecnologia sucroalcooleira: tecnologia do açúcar. $2^{\text {a }}$ ed., Editora ESALQ, USP, Piracicaba, SP, Brasil, $67 \mathrm{p}$.

RIPOLI TCC AND RIPOLI MLC. 2004. Biomassa de canade-açúcar: colheita, energia e ambiente. Ed. Eletrônica. Barros e Marques, Piracicaba, SP, Brasil, 302 p.

RODRIGUES DCGA AND SANTOS TT. 2011. Manual de práticas de processos bioquímicos. Editora UERJ, Rio de Janeiro, RJ, Brasil, 41 p.

RODRIGUES JD. 2013. Sugarcane processes. FMC Square 17: 43-48.

SANTOS DH, SILVA MA, TIRITAN CS, FOLONI JSS AND ECHER FR. 2011. Technological quality of sugarcane under fertilization with filter cake enriched with soluble phosphate. Rev Bras Eng Agríc Ambient 15: 443-449.

SILVA MA, ARANTES MT, RHEIN AFL, GAVA GJC AND KOLLN OT. 2014. Yield potential of sugarcane under drip irrigation in function of varieties and crop cycles. Rev Bras Eng Agríc Ambient 18: 241-249.

SILVA RFS AND SEGATO SV. 2011. Importance of the use of maturity, plant in the culture of sugar cane. Nucleus 8: $35-46$.

SOUZA JL, MOURA FILHO G, LYRA RFF, TEODORO I, SANTOS EA, SILVA JL, SILVA PRT, CARDIM AH AND AMORIM EC. 2004. An assessment of the rainfall and air temperature in the region of Tabuleiro Costeiro of Maceió, AL, Brazil, during the 1972-2001 period. Rev Bras Agrometeorol 12: 131-141.

SOUZA JL, NICÁCIO RM AND MOURA MAL. 2005. Global solar radiation measurements in Maceió, Brazil. Renewable Energy 30: 1203-1220.

TOPPA EVB, JADOSKI CJ, JULIANETTI A, HULSHOF T, ONO EO AND RODRIGUES JD. 2010. Physiology aspects of sugarcane production. Pesqui Apl Agrotec 3: 223-230. 